\title{
ACUTE PERFORATED PEPTIC ULCER: A CLINICAL, DIAGNOSTIC AND MANAGEMENT ANALYSIS IN A TERTIARY HOSPITAL OF TELANGANA
}

\author{
Boda Kumaraswamy ${ }^{1}$ \\ ${ }^{1}$ Assistant Professor, Department of Surgery, Kakatiya Medical College, Warangal, Telangana.
}

\section{ABSTRACT}

Treatment of Peptic Ulcer Disease in major hospitals is now limited to managing their complications like perforations of stomach or duodenum. This is also a common cause of peritonitis and remains a challenge to the surgeon. Diagnosis is based on clinical parameters like pain in the abdomen, shock, abdominal guarding/rigidity and abdominal distension. The diagnosis is confirmed by ultrasound examination of the abdomen, x-ray abdomen in erect posture. The predisposing factors include the age, smoking, alcohol intake, steroids and NSAIDs usage. The risk factors of mortality are presence of shock and pre-existing medical conditions and time of arrival to the casualty. The mortality and morbidity may be predicted using different scoring systems like ASA scoring and Boey's scoring.

\section{AIM}

To analyze the different risk factors, clinical features and surgical treatment options of Acute Peptic Ulcer perforation in patients attending a Tertiary Hospital. To evaluate the prognostic factors causing death and complications in this condition.

\section{MATERIALS AND METHODS}

One hundred and sixty five patients attending with signs and symptoms of Acute Perforation of Peptic Ulcer were included. Males were predominantly affected than females with a 1.94:1 ratio. The median duration of illness was 9.64 days. History of smoking in $93.5 \%$, NSAIDs in 78\%, alcohol intake in $93.8 \%$ and steroids in $84 \%$ of the patients was present. Previous history of peptic ulcer disease was reported in $90 \%$ of the patients. Gastric ulcers were more common than with duodenal ulcer with a ratio of $1.32: 1$. The mortality rate was $6.66 \%$. Among the complications wound infection was highest with $26 \%$ followed by paralytic ileus 23\%. ASA and Boey's scoring showed statistical significance in predicting the mortality with a P value of 0.00003 .

\section{RESULTS}

The incidence of APPU was $0.35 \%$ of the total 46080 emergency surgical patients in a 4-year period. The incidence was high among the manual laborers and in urban populations. The potential risk factors with statistical significance with $P$ value below 0.05 were age, smoking, intake of alcohol, high BUN and serum creatinine levels and time lapse before undertaking definitive treatment.

\section{CONCLUSIONS}

Acute perforation of the peptic ulcer is a common clinical entity in this part of the state of Telangana affecting both the sexes. Simple closure with omental patch followed by treatment of the peptic ulcer disease limits the mortality and morbidity as reported from this center. The ASA and the Boey's scoring helps in assessing the risk factors for post-operative mortality and morbidity.

\section{KEYWORDS}

Peptic Ulcer Disease, Acute Abdomen, Emergency, Perforation, Rigidity, Guarding, ASA Scoring and Boey’s Scoring.

HOW TO CITE THIS ARTICLE: Boda Kumaraswamy. "Acute Perforated Peptic Ulcer: A Clinical, Diagnostic and Management Analysis in a Tertiary Hospital of Telangana." Journal of Evolution of Medical and Dental Sciences 2015; Vol. 4, Issue 98, December 07; Page: 16353-16360, DOI: 10.14260/jemds/2015/2417

\section{INTRODUCTION}

Among the different causes producing Acute Abdominal Surgical Emergency (AASE), Acute Peptic Ulcer Perforation (APUP) remains major contributing factor requiring immediate surgical intervention to avoid complications. Perforations following Peptic Ulcer Disease (PUD) remain a major life threatening complication of chronic peptic ulcer disease. Duodenal ulcers are twice as common as gastric ulcers and males outnumber females by $4: 1{ }^{1}$ Patients with gastric ulcers tend to be elderly and hence a higher mortality than duodenal ulcers explained by a cohort study showing common use of aspirin and other NSAIDs and who also had $\mathrm{H}$. Pylori infection. ${ }^{2}$

Financial or Other, Competing Interest: None

Submission 17-11-2015, Peer Review 18-11-2015,

Acceptance 27-11-2015, Published 07-12-2015.

Corresponding Author:

Dr. Boda Kumaraswamy,

Assistant Professor of Surgery,

Kakatiya Medical College,

Warangal, Telangana.

E-mail: kamreddyashol@gmail.com

DOI:10.14260/jemds/2015/2417
Peptic ulcer perforations are common among the low socioeconomic group and more common in the developing countries than in the West. ${ }^{3,4}$ The risk factors of PUD are $\mathrm{H}$. Pylori, NSAIDs, Smoking, Caffeine, Alcohol and Stress.3,5,6,7 PUD is associated with potentially life-threatening complications including bleeding, perforation, penetration and obstruction. Perforation is the second most frequent complication after bleeding. ${ }^{8}$ Every fifth patient with APUP presents with signs of sepsis and by a careful preoperative assessment of the patient's severity grade, appropriate management can be offered to achieve an optimal outcome of disease. ${ }^{9,10}$ The ASA score and the Boey score are the most frequently used prognostic scoring systems in patients with PPU.11,12 Yet, the ASA score is a general surgical risk score not intended for APUP patients in particular.

Moreover, the external validation of the Boey score is uncertain. In the recent times, use of proton pump inhibitors and Helicobacter pylori eradication has reduced the operative treatment, its complications and recurrence. ${ }^{11}$ Recently $H$. pylori infection is reported in peptic ulcer perforation patients with high prevalence. Although standard treatment is to eradicate $\mathrm{H}$. pylori for uncomplicated and bleeding peptic ulcers, its role in perforation is controversial. 
Hence in addition to patch repair of the perforation, immediate acid-reduction surgery is being recommended for perforated duodenal ulcers. ${ }^{13}$ The factors causing gastroduodenal perforations are traumatic and nontraumatic. Mortality following preliminary surgery for APUP depends upon shock, pre-existing comorbid conditions and time interval between patient arrival and patch-up surgery. The morbidity and mortality can be reduced by avoiding the delays in the diagnosis and treatment. ${ }^{14}$ Recently, Johannes et al. ${ }^{15}$ have shown that persons with blood group 0 have more H. pylori receptors. The present study is conducted to analyze the risk factors, clinical and management criteria among the patients attending a Tertiary Hospital of Telangana.

\section{MATERIALS AND METHODS}

A prospective study was conducted at M. G. M. Hospital (Tertiary) attached to Kakatiya Medical College, Warangal, Telangana, between March 2012 and July 2015 (Four-year period) on 165 patients managed by surgery for Acute Perforated Peptic Ulcer (APPU).

\section{Inclusion Criteria}

1. Patients reporting with acute abdominal pain, guarding/rigidity of the abdomen and history of peptic ulcer disease.

2. Patients aged above 25 years and below 65 years.

3. Patients reporting with clinical features of acute perforation of peptic ulcer between 0-48 Hours. 4. Patients with ASA grading I to III. 5. Patients who were treated with only closure of the perforation with an omental patch (Graham Omentopexy).

\section{Exclusion Criteria}

1. Patients aged below 35 and above 55 years.

2. Patients reporting after 48 hours.

3. Patients with ASA grading above III.

4. Patients who were performed resection surgeries. Demographic data was recorded including age, sex, profession, socioeconomic status, educational background and place of living. Thorough personal history of smoking, intake of alcohol, use of steroids and/or NSAIDs and earlier treatment of peptic ulcer disease were elicited and recorded. Clinical examination parameters like shock (Level of consciousness, sweating, pallor and rapid pulse), abdominal guarding/rigidity, fever, blood pressure and oxygen saturation were recorded.

Immediate resuscitation measures and operative findings and post-operative treatment schedules were recorded. During the surgery of perforation closure, the size of the perforation, post-operative recovery time and stay in the Surgical Intensive Care Unit (SICU). Total hospital stay, outcome of the surgical procedure, complications, morbidity and mortality were recorded for all the patients. The diagnosis of APUP was made from history and physical examinations, plain abdominal and chest radiographs, ultrasound scans of abdomen and pelvis were used. Few patients were diagnosed at laparotomy.

Laboratory investigations like complete hemogram, blood urea, fasting blood sugar, serum creatinine, serum albumin, serum electrolyte study, hemoglobin, blood grouping, ECG and X-ray abdomen in erect posture were performed in all the patients. The patients were resuscitated with the help of intravenous fluid and electrolyte replacement, intravenous antibiotics (third-generation cephalosporins and metronidazole) and nasogastric tube suction to decompress the G.I.T. A urinary output of $>30 \mathrm{ml} / \mathrm{h}$. indicated adequate hydration and resuscitation. Wherever necessary blood was cross matched for and kept reserved for transfusion. Boey's scoring and ASA scorings were used in all the patients to assess the pre-operative status.

Laparotomy was performed after a consultation with the concerned anesthetist using a midline abdominal incision. Abdominal exploration was done to identify the site of perforation, estimate its size, record volume of peritoneal exudates and status of G.I.T. wall surrounding the ulcer (Friability). The perforation was closed using interrupted 2/0 vicyrl sutures tied over pedicled omentum (Graham omentopexy). Peritoneal cavity was washed with adequate warm sterile saline. A vacuum drain was kept in-situ in the abdomen and the abdomen was closed in layers using nonabsorbable material (No: 2 Nylon).

All the surgeries were performed by the Assistant Professors and Associate Professors of the single unit. Senior residents were guided in performing these operations in few patients. Post-operative care was given in the SICU and observation provided by the junior and senior residents, which consisted of intravenous fluids, intravenous antibiotic, metronidazole, nasogastric tube suction until bowel sounds returned and oral feeding commenced. This treatment continued for 1 week.

All the patients progressing and recovering on expected lines were discharged with the treatment of Amoxycillin, metronidazole or Amoxycillin with Clavulanic acid and Pantoprazole for 6 weeks. Patients developing complications were monitored in the SICU and laboratory investigations repeated including $\mathrm{U} / \mathrm{S}$ abdomen to know the cause for delay in recovery. All the complications, morbidity and mortality were recorded and analyzed using multiple logistic regression analysis. Fisher Exact Test calculator and Chi square calculator were used to analyze the data and to calculate the $P$ value. The $P$ value below 0.05 was taken as significant in this study.

\section{OBSERVATIONS AND RESULTS}

The present prospective study included 165 patients with APUP attending the Casualty Department of M. G. M. Hospital attached to Kakatiya Medical College and treated by a single unit of Department of Surgery. Being a tertiary referral hospital catering to the needs of 4 districts of Telangana, the number of general surgery emergency patients attending the Casualty Department per month was 960 which included both minor and major cases. Out of these patients, 165 patients presented with APPU accounting to $0.35 \%$ of the total 46080 emergency surgical patients in a 4-year period. Males were $109(66.06 \%)$ and females were 56(33.93\%) with a male preponderance of 1.94:1.

Patients belonging to the age group between 35 and 55 were present with the mean age of 46.84 in males with Standard Deviation (SD) of 10.96. In female patients, the mean age was 44.83 with an SD of 8.99. Among the male patients 50/109(45.87\%) were above 45 years of age and $59 / 109(54.12 \%)$ patients were below 45 years. In females $21 / 56(37.5 \%)$ were below 45 years and $35 / 56(62.5 \%)$ were above 45 years. The $P$ value for the difference was 0.049 with significance level of $\mathrm{P}$ value taken as 0.05 . Manual laborers were $77(46.66 \%)$ and 88 were non-laborers (53.33\%) with a $P$ value for difference was 0.017 .

The incidence of APUP in the three social status strata was compared and found to be not statistically significant ( $P$ value 0.856 ). Similarly the incidence of APUP was compared according to the education status and place of living (Urban/Rural) and found that the educational status $(\mathrm{p}=$ 0.68 ) has no statistical significance, whereas the place of living has a significance $(\mathrm{p}=0.036)$ (Table1). The median duration of illness was 9.64 days. 


\begin{tabular}{|c|c|c|c|}
\hline Observation & $\begin{array}{c}\text { Age }<45 \\
\text { years } \\
n=80\end{array}$ & $\begin{array}{c}\text { Age }>45 \\
\text { years; } \\
n=85\end{array}$ & $\begin{array}{l}\text { P value for } \\
\text { Difference }\end{array}$ \\
\hline \multicolumn{4}{|l|}{ Gender } \\
\hline Female-56 & 21 & 35 & 0.049 \\
\hline Male-109 & 59 & 50 & \\
\hline Occupation & $\begin{array}{c}\text { Age }<45 \text { Yrs } \\
n=68\end{array}$ & $\begin{array}{c}\text { Age }>45 \text { yrs } \\
n=97\end{array}$ & \\
\hline $\begin{array}{c}\text { Manual } \\
\text { labourer }\end{array}$ & 24 & 53 & 0.017 \\
\hline $\begin{array}{l}\text { Non-manual } \\
\text { labourer }\end{array}$ & 44 & 44 & \\
\hline $\begin{array}{l}\text { Socio- } \\
\text { economic } \\
\text { group }\end{array}$ & $\begin{array}{c}\text { Age }<45 \text { yrs } \\
n=77\end{array}$ & $\begin{array}{c}\text { Age }>45 \text { yrs } \\
n=88\end{array}$ & \\
\hline Low & 32 & 34 & 0.856 \\
\hline Middle & 19 & 25 & \\
\hline Upper & 26 & 29 & \\
\hline Education & $\begin{array}{c}<45 Y r s ; \\
n=76\end{array}$ & $\begin{array}{c}>45 Y r s ; \\
n=91\end{array}$ & \\
\hline Illiterate & 40 & 44 & 0.68 \\
\hline Literate & 36 & 45 & \\
\hline Place of living & $\begin{array}{c}<45 Y r s ; \\
n=65\end{array}$ & $\begin{array}{c}>45 \text { Yrs; } \\
\mathrm{n}=96\end{array}$ & \\
\hline Rural & 40 & 42 & 0.036 \\
\hline Urban & 25 & 54 & \\
\hline$T a b$ & $\begin{array}{r}\text { 1: Showing } \\
\text { of the Stu }\end{array}$ & $\begin{array}{l}\text { mographic } 1 \\
(n=165)\end{array}$ & \\
\hline
\end{tabular}

The clinical presentation of the condition showed that the symptom of severe abdominal pain was present in $96.96 \%$ of the patients followed by fever in $86.06 \%$, abdominal tenderness in $78.78 \%$ and abdominal distension in $74.54 \%$. Dyspepsia was present in $67.27 \%$, vomiting in 48.845 and constipation in $21.81 \%$ of the patients (Table 2).

\begin{tabular}{|c|c|c|}
\hline $\begin{array}{c}\text { Clinical } \\
\text { Presentation }\end{array}$ & $\begin{array}{c}\text { Number of } \\
\text { Patients }\end{array}$ & Percentage \\
\hline Severe abdominal pain & 160 & $96.96 \%$ \\
\hline Vomiting & 74 & $48.84 \%$ \\
\hline Fever & 142 & $86.06 \%$ \\
\hline $\begin{array}{c}\text { Abdominal } \\
\text { distension }\end{array}$ & 123 & $74.54 \%$ \\
\hline Nausea & 85 & $51.51 \%$ \\
\hline Shock & 61 & $36.96 \%$ \\
\hline Constipation & 36 & $21.81 \%$ \\
\hline Abdominal tenderness & 130 & $78.78 \%$ \\
\hline Signs peritonitis & 112 & $64.24 \%$ \\
\hline Dyspepsia & 111 & $67.27 \%$ \\
\hline \multicolumn{2}{|c|}{$\begin{array}{c}\text { Table 2: Showing the Symptoms } \\
\text { and Signs of APPU (n=165) }\end{array}$} \\
\hline \multicolumn{2}{|c|}{}
\end{tabular}

The difference in the personal history of smoking, intake of alcohol, NSAIDs, steroids and previous PUD disease between the males and females showed that it was significant with $\mathrm{p}$ value 0.0005 for smoking, 00 for alcohol intake and for steroids was 0.036 . The relation to the history of NSIADs and previous history of PUD was not significant (Table 3).

\begin{tabular}{|c|c|c|c|}
\cline { 2 - 4 } \multicolumn{1}{c|}{} & Male-109 & Female-56 & ${ }^{\sim}$ P value \\
\hline $\begin{array}{c}\text { Personal } \\
\text { History }\end{array}$ & & & \\
\hline Smokers & $67-61.46 \%$ & $18-32.14 \%$ & \\
\hline Non-smokers & $42-38.53 \%$ & $38-67.85 \%$ & 0.0005 \\
\hline Alcoholic & $79-72.47 \%$ & $12-21.42 \%$ & 00 \\
\hline Non-alcoholic & $30-27.52 \%$ & $44-78.57 \%$ & N.S. \\
\hline NSAIDs & $55-55.45 \%$ & $23-41.07 \%$ & 0.036 \\
\hline Steroids & $62-56.88 \%$ & $16-28.57 \%$ & \\
\hline $\begin{array}{c}\text { None, but } \\
\text { previous h/o } \\
\text { PUD }\end{array}$ & $63-57.79 \%$ & $19-33.92 \%$ & \\
\hline \multicolumn{4}{|c|}{$\begin{array}{l}\text { Table 3: Showing the Personal History } \\
\text { Data between Males and Females (n=165) }\end{array}$} \\
\hline
\end{tabular}

The clinical signs of shock, abdominal guarding/rigidity, fever, blood pressure and oxygen saturation were observed at the time of admission in all the patients. It was found that the difference between patients above 45 and below 45 years was found to be statistically not significant in relation to all parameters except the blood pressures (0.001) ( Table 4).

\begin{tabular}{|c|c|c|c|}
\hline $\begin{array}{c}\text { Clinical } \\
\text { Parameters }\end{array}$ & $\begin{array}{c}<45 \text { years } \\
n=80\end{array}$ & $\begin{array}{c}>45 \\
n=85\end{array}$ & $\begin{array}{c}\sim P \\
\text { value }\end{array}$ \\
\hline Shock & $39-48.75 \%$ & $55-64.70 \%$ & \\
\hline $\begin{array}{c}\text { Abdominal } \\
\text { guarding/rigidity }\end{array}$ & $74-92.5 \%$ & $81-95.29 \%$ & \\
\hline Fever & $80-100 \%$ & $85-100 \%$ & 0.837 \\
\hline \multicolumn{4}{|l|}{ Blood pressure } \\
\hline $\begin{array}{l}\text { Systolic Above } \\
90 \mathrm{mmHg}\end{array}$ & $56-70 \%$ & $41-48.23 \%$ & \\
\hline $\begin{array}{l}\text { Systolic below } \\
90 \mathrm{mmHg}\end{array}$ & $24-30 \%$ & $44-51.76 \%$ & 0.001 \\
\hline \multicolumn{4}{|l|}{ Oxygen Saturation } \\
\hline Above $90 \%$ & $25-31.25 \%$ & $22-25.88 \%$ & 0.531 \\
\hline Below 90\% & $55-68.75 \%$ & $63-74.11 \%$ & \\
\hline \multicolumn{4}{|c|}{$\begin{array}{c}\text { Table 4: Showing Clinical Examination Data between } \\
\text { Patients Above and Below } 45 \text { years }(n=165)\end{array}$} \\
\hline
\end{tabular}

The laboratory investigations which included Hemoglobin, BUN, FBS, serum creatinine, serum albumin and $\mathrm{x}$-ray abdomen in erect posture were compared between patients aged above 45 and below 45 years. It was found the difference to be significant statistically in all parameters except serum creatinine and x-ray abdomen in the present study (Table 5). 


\begin{tabular}{|c|c|c|c|}
\hline $\begin{array}{c}\text { Lab } \\
\text { Investigations }\end{array}$ & $\begin{array}{c}<45 \\
\text { years- } \\
80\end{array}$ & $\begin{array}{c}>45 \\
\text { years- } \\
85\end{array}$ & $\begin{array}{c}\begin{array}{c}\text { P value for } \\
\text { the } \\
\text { Difference }\end{array} \\
\end{array}$ \\
\hline \multicolumn{4}{|l|}{ Hemoglobin } \\
\hline $\begin{array}{l}\text { More than } \\
10 \mathrm{Gms} / \mathrm{dl}\end{array}$ & 61 & 52 & \multirow{2}{*}{0.047} \\
\hline $\begin{array}{l}\text { Less than } \\
10 \mathrm{Gms} / \mathrm{dl}\end{array}$ & 19 & 33 & \\
\hline \multicolumn{3}{|l|}{ BUN } & \multirow{3}{*}{0.047} \\
\hline$>45 \mathrm{mg} / \mathrm{dl}$ & 58 & 49 & \\
\hline$<45 \mathrm{mg} / \mathrm{dl}$ & 22 & 36 & \\
\hline \multicolumn{3}{|l|}{$\begin{array}{c}\text { Fasting blood } \\
\text { sugar (FBS) }\end{array}$} & \multirow{3}{*}{0.019} \\
\hline$>110 \mathrm{mg} / \mathrm{dl}$ & 38 & 56 & \\
\hline$<110 \mathrm{mg} / \mathrm{dl}$ & 42 & 29 & \\
\hline \multicolumn{3}{|l|}{ Serum creatinine } & \multirow{3}{*}{0.411} \\
\hline$>1.47 \mathrm{mg} / \mathrm{dl}$ & 24 & 31 & \\
\hline$<1.47 \mathrm{mg} / \mathrm{dl}$ & 56 & 54 & \\
\hline \multicolumn{3}{|l|}{ Serum Albumin } & \multirow{3}{*}{0.002} \\
\hline$>1.5 \mathrm{Gms} / \mathrm{L}$ & 36 & 58 & \\
\hline$<1.5 \mathrm{Gms} / \mathrm{L}$ & 44 & 27 & \\
\hline $\begin{array}{l}\text { X-ray abdomen/ } \\
\text { erect with Air } \\
\text { under diaphragm- } \\
111(67.27 \%)\end{array}$ & 61 & 40 & N.S. \\
\hline \multicolumn{4}{|c|}{ Table 5: Showing the Lab Investigations Data ( $n=165)$} \\
\hline
\end{tabular}

The site of ulcer on abdominal exploration was found in both the duodenum and stomach, the former was present in $53(32.12 \%)$ and $41(24.84 \%)$ in patients aged below 45 years and above 45 years respectively. Gastric ulcer was observed in $27(16.36 \%)$ in aged below 45 years and $44(26.66 \%)$ in aged above 45 years patients respectively. The difference was statistically significant with $\mathrm{p}$ value 0.027 . Duodenal ulcers were more common than with gastric ulcers with a ratio of 1.32 to 1 . Surgery undertaken within 24 hours of onset of the symptoms was found in $52(31.51 \%)$ in aged below 45 years and $41(24.84 \%)$ in patients aged above 45 years. Surgery done after 24 hours in patients aged below 45 years in $28(16.96 \%)$ and $44(26.66 \%)$ above 45 of age. The difference was significant statistically with p value 0.044 .

\begin{tabular}{|c|c|c|c|}
\hline Observation & $\begin{array}{c}<45 \text { yrs- } \\
n=80\end{array}$ & $\begin{array}{c}>45 \text { yrs- } \\
n=85\end{array}$ & $\begin{array}{l}\text { P value for } \\
\text { Difference }\end{array}$ \\
\hline Site of Ulcer & & & \multirow{3}{*}{0.027} \\
\hline Gastric Ulcer & 27 & 44 & \\
\hline Duodenal Ulcer & 53 & 41 & \\
\hline $\begin{array}{l}\text { Delay to surgery } \\
\text { (Hours) }\end{array}$ & & & \multirow{3}{*}{0.044} \\
\hline $\begin{array}{l}\text { Less than } \\
24 \text { hours }\end{array}$ & 52 & 41 & \\
\hline $\begin{array}{l}\text { More than } \\
24 \text { hours }\end{array}$ & 28 & 44 & \\
\hline $\begin{array}{l}\text { Volume of } \\
\text { Exudates }\end{array}$ & & & \multirow{3}{*}{0.022} \\
\hline$>1000 \mathrm{ml}$ & 37 & 29 & \\
\hline$<1000 \mathrm{ml}$ & 33 & 56 & \\
\hline \multicolumn{4}{|l|}{$\begin{array}{c}\text { Size of } \\
\text { Perforation }(5- \\
15 \mathrm{~mm})\end{array}$} \\
\hline $\begin{array}{c}\text { Pre-op } \\
\text { Peritonitis- } \\
97(58.78 \%)\end{array}$ & $\begin{array}{c}47 \\
(28.485)\end{array}$ & $\begin{array}{c}43 \\
(26.06 \%)\end{array}$ & \\
\hline $\begin{array}{r}\text { Table 6: } S \\
\text { Observa }\end{array}$ & $\begin{array}{l}\text { wing Per } \\
\text { is Relate }\end{array}$ & $\begin{array}{l}\text { ld Per-Ope } \\
\text { APPU (n) }\end{array}$ & $\begin{array}{l}\text { ative } \\
65)\end{array}$ \\
\hline
\end{tabular}

The volume of exudates less than $1000 \mathrm{ml}$ was observed in $37(22.42 \%)$ of patients aged below 45 years and $29(17.57 \%)$ of them aged above 45 years. More than $1000 \mathrm{ml}$ exudates was found in $33(20 \%)$ and $56(33.93 \%)$ of them aged above 45 years (Table 6). There were 11(6.66\%) deaths in the present study in spite of surgical intervention due to different risk factors. The remaining patients recovered well without any further complications with a success rate of 93.33\%.

The mortality and morbidity in the patients when correlated to various risk factors, it was found that the age was statistical significant risk factor with a $p$ value of 0.003 in both the group of patients aged above and below 45 years. Similarly presence of shock at the time of admission was significant with $\mathrm{p}$ value 0.00001 in patients who did not survive and 0.0054 in those who survived but with morbidity. BUN levels above $45 \mathrm{mg} / \mathrm{dl}$, serum creatinine above $1.44 \mathrm{mg} / \mathrm{dl}$ and serum albumin below $1.5 \mathrm{gms} / \mathrm{L}$ were statistically significant with $\mathrm{p}$ value 0.00 in patients who succumbed.

Levels of hemoglobin, pulse rate, blood pressures (Systolic and diastolic) and operation time were not significant factors in assessing the mortality of APPU in this study with $\mathrm{p}$ values more than 0.05. Similarly size of perforation was not significant factor in all sizes except in patients showing morbidity with perforation size $0.5 \mathrm{~cm}$ to $1 \mathrm{~cm}$ with $\mathrm{p}$ value 0.0011 . Presence of premorbid illnesses was significantly a risk factor in the present study as the $p$ value was 0.00001 (Table 7). 


\begin{tabular}{|c|c|c|c|c|c|c|}
\hline $\begin{array}{c}\text { Observation - Mean } \\
\text { Values }\end{array}$ & Mortality & No Mortality & $\mathbf{P}$ & Morbidity & No Morbidity & $\mathbf{P}$ \\
\hline & $\mathrm{n}=11(6.7 \%)$ & $\begin{array}{c}\mathrm{n}=154 \\
(93.33 \%)\end{array}$ & & $\begin{array}{c}\mathrm{n}=41 \\
(24.84 \%)\end{array}$ & $\begin{array}{l}\mathrm{n}=124 \\
(75.15 \%)\end{array}$ & \\
\hline Age (years) (mean \pm SD) & $43.5 \pm 06.1$ & $34.4 \pm 2.4$ & $\begin{array}{c}0.00 \\
3\end{array}$ & $40.4 \pm 4.1$ & $33.2 \pm 09.8$ & 0.003 \\
\hline Sex; Male/Female (n, \%) & $\begin{array}{c}07(63.63 \%) / \\
4(36.36 \%) \\
\end{array}$ & $\begin{array}{c}102(66.23 \%) / \\
52(33.76 \%)\end{array}$ & N.S & $\begin{array}{l}24(58.53 \%) / \\
17(41.46 \%) \\
\end{array}$ & $\begin{array}{c}85(68.54 \%) / \\
39(31.45 \%) \\
\end{array}$ & N.S. \\
\hline Shock- Present & $10(90.90 \%)$ & $12(7.79 \%)$ & $\begin{array}{l}0.00 \\
001\end{array}$ & 09 (21.95\%) & $10(8.06 \%)$ & 0.0054 \\
\hline Shock Absent & $1(9.09 \%)$ & $142(92.20 \%)$ & & $32(78.04 \%)$ & $114(91.93 \%)$ & \\
\hline $\begin{array}{l}\text { Hemoglobin }(\mathrm{g} / \mathrm{dl}) \\
(\text { mean } \pm \mathrm{SD})\end{array}$ & $10.6 \pm 2.8$ & $14 \pm 1.3$ & N.S & $12.3 \pm 1.2$ & $15.4 \pm 1.1$ & N.S \\
\hline $\begin{array}{c}\text { BUN }(\mathrm{mg} / \mathrm{dl})(\text { mean } \pm \mathrm{SD})- \\
\text { No. of patients- above } \\
45 \mathrm{mg} / \mathrm{dl}\end{array}$ & $\begin{array}{c}113.5 \pm 36 \\
9(81 \%)\end{array}$ & -- & 0.00 & $\begin{array}{l}64.5 \pm 37.4 \\
24(15 \%)\end{array}$ & -- & 0.00 \\
\hline $\begin{array}{c}\mathrm{BUN}(\mathrm{mg} / \mathrm{dl})(\mathrm{mean} \pm \mathrm{SD})- \\
\text { below } 45 \mathrm{mg} / \mathrm{dl} \\
\text { No. of patients }\end{array}$ & & $\begin{array}{l}32.6 \pm 24.6 \\
2(18 \%)\end{array}$ & & -- & $\begin{array}{c}35.4 \pm 36.2 \\
130\end{array}$ & \\
\hline $\begin{array}{l}\text { Creatinine(mg/dl) } \\
(\text { mean } \pm \text { SD)/above }\end{array}$ & $\begin{array}{l}2.1 \pm 2.1 \\
8(73 \%)\end{array}$ & -- & & $\begin{array}{c}1.78 \pm 1.32 \\
47(30 \%)\end{array}$ & & \\
\hline $\begin{array}{l}\text { Creatinine(mg/dl) } \\
(\text { mean } \pm \text { SD)/above }\end{array}$ & -- & $\begin{array}{l}1.23 \pm 0.66 \\
2(27 \%) \\
\end{array}$ & 0.00 & & $\begin{array}{l}1.20 \pm 1.21 \\
107(69 \%)\end{array}$ & 0.00 \\
\hline $\begin{array}{c}\text { Albumin (g/L) } \\
\text { (mean } \pm \text { SD) }->1.5 \mathrm{gms} / \mathrm{L}\end{array}$ & $\begin{array}{l}2.86 \pm 0 . \\
7(67 \%)\end{array}$ & & 0.00 & $\begin{array}{c}3.12 \pm 1.22 \\
27(17.53 \%)\end{array}$ & & \\
\hline $\begin{array}{c}\text { Albumin }(\mathrm{g} / \mathrm{L}) \\
(\text { mean } \pm \text { SD) }->1.5 \mathrm{gms} / \mathrm{L}- \\
<1.5 \mathrm{Gms} / \mathrm{L}\end{array}$ & & $\begin{array}{l}951.22 \pm 0.7 \\
3(27)\end{array}$ & & & $\begin{array}{c}3.09 \pm 1.0 \\
127(82.46 \%)\end{array}$ & 0.00 \\
\hline $\begin{array}{c}\mathrm{BP}-\mathrm{S}^{*}(\mathrm{~mm} / \mathrm{Hg}) \\
(\mathrm{mean} \pm \mathrm{SD})\end{array}$ & $90 \pm 28.4$ & $110.24 \pm 21.7$ & N.S. & $\begin{array}{c}130.14 \pm 28 \\
6 \\
\end{array}$ & $132.44 \pm 21.2$ & N.S. \\
\hline $\begin{array}{l}\text { BP-D** }(\mathrm{mm} / \mathrm{Hg}) \\
(\text { mean } \pm \mathrm{SD})\end{array}$ & $60.2 \pm 12.4$ & $92.64 \pm 14.8$ & & $80.2 \pm 14.80$ & $88.4 \pm 10.28$ & \\
\hline Pulse $(/$ min $)($ mean \pm SD $)$ & $113.2 \pm 30.2$ & $94.7 \pm 14.3$ & N.S & $\begin{array}{c}114.6 \pm 20.2 \\
4\end{array}$ & $\begin{array}{c}120.40 \pm 12.2 \\
2\end{array}$ & N.S \\
\hline \multicolumn{7}{|l|}{$\begin{array}{l}\text { Time from perforation to } \\
\text { surgery }(\mathrm{h})(\mathrm{n}, \%)\end{array}$} \\
\hline$<24 \mathrm{~h}$ & $1(9.09 \%)$ & $43(27.92 \%)$ & & $11(26.82)$ & $32(20.77 \%)$ & \\
\hline$>24 \mathrm{~h}$ & $10(90.90 \%)$ & $111(72 \%)$ & $\begin{array}{c}0.00 \\
08\end{array}$ & $30(73.17 \%)$ & $92(74.19 \%)$ & N.S. \\
\hline \multicolumn{7}{|l|}{$\begin{array}{c}\text { Perforation size }(\mathrm{cm})(\mathrm{n}, \\
\%)\end{array}$} \\
\hline$<0.5$ & $03(27.27 \%)$ & $76(49.35 \%)$ & N.S & $11(26.82 \%)$ & $45(36.29 \%)$ & \\
\hline $0.5-1$ & $04(36.36 \%)$ & $36(23.37 \%)$ & N.S & $22(53.65 \%)$ & $36(29.03 \%)$ & 0.0011 \\
\hline$>1$ & $04(36.36 \%)$ & $42(27.27 \%)$ & N.S & $08(19.51 \%)$ & $43(34.67 \%)$ & \\
\hline $\begin{array}{l}\text { Operation time (min) } \\
(\text { mean } \pm \text { SD) }\end{array}$ & $110.3 \pm 22.5$ & $92.4 \pm 28.3$ & & $96.7 \pm 26.4$ & $90.2 \pm 12.8$ & N.S. \\
\hline \multicolumn{7}{|l|}{$\begin{array}{l}\text { Other medical illnesses } \\
(\mathrm{n}, \%)\end{array}$} \\
\hline Absent & $2(18.18 \%)$ & $92(59.74 \%)$ & $\begin{array}{l}0.00 \\
001\end{array}$ & $18(43.90 \%)$ & $100(80.64 \%)$ & $\begin{array}{c}0.0000 \\
1\end{array}$ \\
\hline Present & $09(81.81 \%)$ & $22(14.28 \%)$ & & $23(56.09 \%)$ & $24(19.35 \%)$ & \\
\hline
\end{tabular}

Observing the risk factors causing mortality using ASA and Boey's scoring systems in the present study with 11 deaths; it was found that both the scoring systems were significant statistically with p value 0.00003 in assessing the risk factors (Table 8). 


\begin{tabular}{|c|c|c|c|c|c|c|c|c|}
\hline & \multicolumn{3}{|c|}{ ASA Scoring } & \multicolumn{3}{|c|}{ Boey Scoring } & \multirow[b]{2}{*}{ Percentage } & \multirow[b]{2}{*}{ P value } \\
\hline $\begin{array}{c}\text { No. of } \\
\text { Mortality } \\
\text { Patients- } \\
11\end{array}$ & Observation & Score & Percentage & Observation & Score & $\begin{array}{c}\text { No. of } \\
\text { Mortality } \\
\text { Patients- } \\
11\end{array}$ & & \\
\hline 1 & $\begin{array}{l}\text { Normal } \\
\text { health }\end{array}$ & 1 & $9.09 \%$ & $\begin{array}{l}\text { Medical } \\
\text { illness }\end{array}$ & 1 & 1 & $9.09 \%$ & \\
\hline 02 & $\begin{array}{l}\text { Mild systemic } \\
\text { disease }\end{array}$ & 2 & $18.18 \%$ & $\begin{array}{l}\text { Preoperative } \\
\text { shock }\end{array}$ & 2 & 10 & $90.90 \%$ & 0.00003 \\
\hline 07 & $\begin{array}{l}\text { Severe } \\
\text { systemic } \\
\text { disease }\end{array}$ & 3 & $63.63 \%$ & $\begin{array}{c}\text { Duration of } \\
\text { peptic ulcer } \\
\text { perforation }> \\
24 \mathrm{~h}\end{array}$ & 3 & 10 & $90.90 \%$ & \\
\hline & 8: Showing t & ignifi & e of $A S A$ anc & ey's Scoring S & tems $\mathrm{i}$ & edicting $t$ & Mortality (n & \\
\hline
\end{tabular}

The morbidity is assessed by the post-operative complications developing during convalescent period of 30 days after surgery. They were wound infection in $26 \%$ of the patients, pyrexia in $39 \%$, paralytic ileus in $23 \%$, persistence of peritonitis in $16 \%$ and septic shock in 19\% of the patients (Table 9). The other complications were like intra-abdominal abscess, re-perforation, wound dehiscence, Incisional hernia and pulmonary infection are shown with their incidence in the Table 9.

\begin{tabular}{|c|c|}
\hline Complications & Percentage \\
\hline Wound infection & 26.0 \\
\hline Pyrexia & 39.0 \\
\hline Paralytic ileus & 23.0 \\
\hline Intra-abdominal abscess & 10.0 \\
\hline Septic shock & 19.0 \\
\hline Re-perforation & 09.0 \\
\hline $\begin{array}{l}\text { Wound dehiscence/burst } \\
\text { abdomen }\end{array}$ & 11.0 \\
\hline Enterocutaneous fistula & 08.0 \\
\hline Persistent peritonitis & 16.0 \\
\hline Incisional hernia & 8.0 \\
\hline Cardiopulmonary arrest & 8.0 \\
\hline Acute renal failure & 4.0 \\
\hline Pulmonary infection & 4.0 \\
\hline \multicolumn{2}{|c|}{$\begin{array}{c}\text { Table 9: Showing the Post-operative } \\
\text { Complications }(n=165)\end{array}$} \\
\hline
\end{tabular}

literate were $81(49.09 \%)$ and among them 77(46.66\%) were laborers.

This is in correlation to the study by Phillipo Chalya. ${ }^{18}$ According to them, this observation has an implication to the accessibility of health services and awareness of the disease. In the present study the number of patients reporting to Emergency Department after onset of the symptoms before and after 24 hours is almost equal to 87 and 88 respectively. In their study, Nuhu et al. ${ }^{14,18}$ patients reporting later than 24 hours are more in number and they attribute this as a risk factor in the outcome of treatment.

It also denotes inaccessibility to the medical facilities in that country. Patients presenting with pain as the main symptom was observed in $96.96 \%$ of the patients in this study similar to a study by Ajao OG, et al. ${ }^{21}$ Perforated duodenal ulcer is a major complication of chronic peptic ulcer disease. Simple omental patch by open method and Helicobacter pylori eradication therapy is sufficient to prevent reperforation. ${ }^{22}$ B. Eradication of $\mathrm{H}$. pylori prevents ulcer recurrence in patients with $H$. pylori-associated perforated duodenal ulcers. Immediate acid-reduction surgery in the presence of generalized peritonitis is unnecessary. ${ }^{23}$

Moller $\mathrm{MH}$, Shah K, et al. from their study of evaluation of risk factors for treated peptic ulcer perforation concluded that the pre-operative metabolic acidosis, renal insufficiency at admission, insufficient post-operative nutrition are newly added risk factors for death within 30 days of surgery. In addition to shock, these factors play an independent role for deaths occurring within 30 days of surgery and could indicate that patients with acute peptic ulcer perforation are septic on admission. The patients would benefit from a perioperative care protocol with early source control and early goaldirected therapy. 9

Anabria A, et al. in their comparative study of the effect of laparoscopic surgical treatment versus open surgical treatment in patients with a diagnosis of perforated peptic ulcer in relation to abdominal septic complications, surgical wound infection, extra-abdominal complications, hospital length of stay and direct costs concluded that a decrease in septic abdominal complications may exist when laparoscopic surgery is used to correct perforated peptic ulcer. 
However, it is necessary to perform more randomized controlled trials with a greater number of patients to confirm such an assumption, guaranteeing a long learning curve for participating surgeons. ${ }^{24}$ Boey J, et al. validated the risk factors like major medical illness, pre-operative shock and perforation untreated for more than 24 hours resulting in mortality and morbidity in APUP patients in their study. They concluded that the mortality rate increased with increase in number of risk factors and they underscore the importance of patient selection and the feasibility of a risk grading system in deciding the surgical management.

They quoted that "Simple closure is preferable in those patients with uncomplicated perforations if any risk factor is present. Truncal vagotomy and drainage may be required if there is coexisting bleeding or stenosis. Non-operative treatment deserves re-evaluation in patients with all three risk factors because of their uniformly dismal outcome after operation. ${ }^{25}$ Using Boey score, Lohsiriwat V, et al. in their study of 152 patients concluded that APUP is associated with high rates of mortality and morbidity.

The Boey risk score serves as a simple and precise predictor for postoperative mortality and morbidity. ${ }^{26}$ Unver M, Firat Ö, et al. concluded from their study that the duration of symptoms had no effect on mortality or morbidity of patients with APUP. ${ }^{27}$ Forsmo HM, et al. found from their clinical study of APUP patients and concluded that the high mortality and a high frequency of postoperative complications are mainly determined by the patient's age and ASA classification. ${ }^{28}$ Review of literature shows many scoring systems being used to predict the mortality and morbidity rates depending on the risk factors.

The scoring systems are based on eliciting then history, age, laboratory tests like Albumin and BUN. Boey scoring system uses age factor, that age over 60 or 65 was an independent risk factor. In practical scoring system of mortality in patients with perforated peptic ulcer (POMPP) scoring system BUN is used as it is regulated as a result of protein catabolism, steroid intake and G.I.T. bleeding, regardless of function of the kidneys. ${ }^{29}$ Khuri et al. found BUN levels above $40 \mathrm{mgs} / \mathrm{dl}$ were to increase 30 -day mortality rate after non-cardiac operations. ${ }^{30}$ In Peptic Ulcer Perforation Score (PULP) and Jabalpur scoring systems, high level of serum creatinine was used in predicting risk for mortality. ${ }^{31}$

Thorsen et al. considered a serum creatinine level over $1.33 \mathrm{mg} / \mathrm{dl}$ as an independent risk factor that indicates mortality risk in PPU. ${ }^{32}$ In addition they concluded that high creatinine levels with hypoalbuminemia denote a chronic severe disease causing dehydration or accompany infection or sepsis. ${ }^{32}$ Hypoalbuminemia alone is also a risk factor of raised morbidity or mortality as stated by. 33 Thorsen et al. was found that hypoalbuminemia was a strong factor which might determine mortality solely (AUC:0.78). ${ }^{32}$

The correlation between hypoalbuminemia and mortality in PULP is due to reduction in synthesis of albumin in patients with dehydration, hepatic dysfunction, cancer, critical clinical course, systemic inflammatory response syndrome and sepsis. ${ }^{34}$ Studies have analyzed the mortality prediction in PULP patients using ASA status and found AUC values 0,73 and $0,91.11,32$ ASA is purely based on the comorbid status and the severity of the preoperative patient and not specific to peptic ulcer perforation patients. ${ }^{35}$

Besides the main problem of ASA scoring is that calculation is performed subjectively and differences between interpretations may be observed. ${ }^{36}$ Ebru Menekse, Belma Kocer, et al. in their comparative study of scoring systems for PULP concluded that three very clear parameters (Age, albumin and BUN) can be easily adopted in the clinical practice to predict the surgical mortality of PPU patients. ${ }^{37}$ They also concluded that respiratory support, circulatory stabilization, preoperative and postoperative care in ICU, frequent monitoring and perioperative care protocols can be added to the high risk patients with PPU as suggested by Moller and Adamsen, et al.9,11

\section{CONCLUSIONS}

Acute perforations of the peptic ulcers is not an uncommon disease entity presenting to the Emergency Surgical Department. The etiological factors are smoking habit, alcoholism, use of NSAIDs and steroids. The lab investigations predicting the outcome of these patients are BUN, serum albumin and serum creatinine. The prognostic factors are age, sex, ASA scoring and Boey's scoring preoperatively. The time of arrival after the onset of symptoms, blood pressure values and shock give a significant predictability in the mortality. The morbidity depends upon the pre-existing medical diseases and postoperative treatment schedule implemented In the present study, simple omental patch by open method and postoperative helicobacter treatment and health education to avoid predisposing factors of peptic ulcer disease helped in achieving $93.33 \%$ success rate.

\section{REFERENCES}

1. Courtney M. Townsend: SABISTON Textbook of Surgery. Stomach. Elsevier, USA. 18 ${ }^{\text {th }}$ ed. 2008;47:1236-56.

2. Bruce E Jarrell; Anthony Carabasi R: NMS Surgery. Stomach and Duodenum. Lippincott Williams \& Wilkins, Philadelphia. $5^{\text {th }}$ ed. 2007;11:203-9.

3. Charles Brunicardi F: Schwartz' Principles of Surger. Stomach. The McGraw-Hill Companies, USA, $9^{\text {th }}$ Edition. 2010;26:907-22.

4. Bruce E Jarrell; Anthony Carabasi R: NMS Surgery. Stomach and Duodenum. Lippincott Williams \& Wilkins, Philadelphia. $5^{\text {th }}$ ed. 2007;11:203-9.

5. Koivisto TT, Voutilainen ME, Färkkilä MA. Effect of smoking on gastric histology in Helicobacter pyloripositive gastritis.

Scand J Gastroenterol 2008;43:1177-83.

6. Aldoori WH, Giovannucci EL, Stampfer MJ, Rimm EB, Wing AL, Willett WC. A prospective study of alcohol, smoking, caffeine and the risk of duodenal ulcer in men. Epidemiology 1997;8:420-4.

7. Karp, Seth J; Morris, James PG, et al. Blueprints Surgery. Stomach and duodenum. Lippincott Williams \& Wilkins, Philadelphia. $5^{\text {th }}$ ed. 2004;3:21-25.

8. Christensen S, Riis A, Norgaard M, Sørensen HT, Thomsen RW:Short-term mortality after perforated or bleeding peptic ulcer among elderly patients: a population-based cohort study. BMC Geriatr 2007;7:8.

9. Moller MH, Shah K, Bendix J, Jensen AG, ZimmermannNielsen E, Adamsen S, Moller AM. Risk factors in patients surgically treated for peptic ulcer perforation. Scand J Gastroenterol 2009;44, 2:145-152.

10. Moller MH, Adamsen S, Thomsen RW, Moller AM: Multicentre trial of a perioperative protocol to reduce mortality in patients with peptic ulcer perforation. Br J Surg 2011;98, 6:802-810.

11. Lohsiriwat V, Prapasrivorakul S, Lohsiriwat D: Perforated peptic ulcer: clinical presentation, surgical outcomes and the accuracy of the Boey scoring system in predicting postoperative morbidity and mortality. World J Surg 2009;33(1):80-85.

12. Pedersen T, Eliasen K, Ravnborg M, Viby-Mogensen J, Qvist J, Johansen SH, Henriksen E: Risk factors, complications and outcome in anaesthesia. A pilot study. Eur J Anaesthesiol 1986;3, 3:225-239. 
13. Kenneth Thorsen, Jon Arne Søreide and Kjetil Søreide. Scoring systems for outcome prediction in patients with perforated peptic ulcer. Scandinavian Journal of Trauma, Resuscitation \& Emergency medicine 2013;21:25.

14. Nuhu A, Kassama Y. Experience with acute perforated duodenal ulcer in a West African population. Niger J Med 2008;17(4):403-6.

15. Johannes G, Kusters, Arnoud HM, Van Vliet and Ernst J Kuipers. Pathogenesis of Helicobacter pylori Infection. Clin Microbiol Rev 2006;19. 3:449-490.

16. Ng EK ${ }^{1}$, Lam YH, Sung JJ, Yung MY, To KF, Chan AC, Lee DW, Law BK, Lau JY, Ling TK, Lau WY, Chung SC. Eradication of Helicobacter pylori prevents recurrence of ulcer after simple closure of duodenal ulcer perforation: randomized controlled trial. Ann Surg 2000;231, 2:153-8.

17. Schein M, Saadia R, Decker GA: Perforated peptic ulcer at the JG Strijdom Hospital: A retrospective study of 99 patients. S Afr Med J 1986;70(5):21-23.

18. Mieny CJ, Kopelowitz W, Colsen P: Management of perforated peptic ulcer. S Air] Surg 1974;12:27-29.

19. Phillipo L, Chalya, Joseph B, Mabula, Mheta Koy, Mabula D, Mchembe, Hyasinta M Jaka, Rodrick Kabangila, Alphonce B Chandika and Japhet M Gilyoma. Clinical profile and outcome of surgical treatment of perforated peptic ulcers in Northwestern Tanzania: A Tertiary Hospital experience.

World Journal of Emergency Surgery 2011;6:31.

20. Türkdoğan MK, Hekim H, Tuncer I, Aksoy H: The epidemiological and endoscopic aspects of peptic ulcer disease in Van region. Eastern Journal of Medicine 1999;4(1):6-9.

21. Kang JY, Elders A, Majeed A: Recent trend in hospital admission and mortality rate for peptic ulcer in Scotland 1982-2002. Aliment Pharmacol Ther 2006;24(1):65-79.

22. Ajao OG: Perforated duodenal ulcer in a tropical African population. J Natl Med Assoc 1979;71:272-3.

23. Bas G, Eryilmaz R, Okan I, Sahin M. Risk factors of morbidity and mortality in patients with perforated peptic ulcer. Acta Chir Belg 2008;108:424-27.

24. Kanbay M, Gür G, Arslan H, Yilmaz U, Boyacioglu S. The relationship of $\mathrm{ABO}$ blood group, age, gender, smoking, and Helicobacter pylori Infection. Dig Dis Sci 2005;50:1214-7.
25. Sanabria A, Villegas MI, Morales Uribe CH. Laparoscopic repair for perforated peptic ulcer disease. Cochrane Database Syst Rev 2013, Feb 28.

26. Boey J, Choi SK, Poon A, Alagaratnam TT. Risk stratification in perforated duodenal ulcers. A prospective validation of predictive factors. Ann Surg 1987;205, 1. 22-6.

27. Lohsiriwat V, Prapasrivorakul S, Lohsiriwat D. Perforated peptic ulcer: clinical presentation, surgical outcomes and the accuracy of the Boey scoring system in predicting postoperative morbidity and mortality. World J Surg 2009;331:80-5.

28. Unver M, Fırat Ö, Ünalp ÖV, Uğuz A, Gümüş T, Sezer TÖ, Öztürk Ş, Yoldaş T, Ersin S, Güler A. Prognostic factors in peptic ulcer perforations: a retrospective 14-year study. Int Surg 2015;100, 5. 942-8.

29. Forsmo HM, Glomsaker T, Vandvik PO. Perforated peptic ulcer--a 12-year material. Tidsskr Nor Laegeforen 2005;125. 13. 1822-24.

30. Uchino S, Bellomo R, Goldsmith D. The meaning of the blood urea nitrogen/creatinine ratio in acute kidney injury. Clin Kidney J 2012;5. 187-91.

31. Owens WD. American Society of Anesthesiologists Physical Status Classification System in not a risk classification system. Anesthesiology 2001;94:378.

32. Mishra A, Sharma D, Raina VK. A simplified prognostic scoring system for peptic ulcer perforation in developing countries. Indian J Gastroenterol 2003;22. 49-53.

33. Thorsen K, Søreide JA, Søreide K. What is the best predictor of mortality in perforated peptic ulcer disease? A population-based, multivariable regression analysis including three clinical scoring systems. I Gastrointest Surg 2014;18. 1261-8.

34. Møller MH, Adamsen S, Thomsen RW, Møller AM. Preoperative prognostic factors for mortality in peptic ulcer perforation: a systematic review. Scand J Gastroenterol 2010;45. 785-805.

35. Ñamendys-Silva SA, González-Herrera MO, TexcocanoBecerra J, Herrera-Gómez A. Hypoalbuminemia in critically ill patients with cancer: incidence and mortality. Am J Hosp Palliat Care 2011;28. 253-7.

36. Daabiss M. American Society of Anaesthesiologists physical status classification. Indian J Anaesth 2011;55. 111-5. 